\title{
THE EFFECT OF TOOL PRESS FORCE TO WELDABILITY OF AA5754 AND AA6061 ALLOYS WITH FRICTION STIR WELDING METHOD
}

\author{
Tevfik KÜÇÜKÖMEROĞLU $U^{1 *}$, Hasan YILMAZ2, Semih Mahmut AKTARER ${ }^{3}$
}

\author{
1Mechanical Engineering Deparment, Engineering Faculty, Karadeniz Technical University, 61080, Trabzon \\ tkomer@ktu.edu.tr
}

2Deparment of Construction and Technical Works, Giresun Univesity, 28200, Giresun hayilmaz28@hotmail.com

${ }^{3}$ Automotive Programme, Vocational High School, Recep Tayyip Erdoğan University, 53100, Rize

semih.aktarer@erdogan.edu.tr

Received: 03.01.2013, Accepted: 22.01.2013

doi: $10.5505 /$ pajes.2013.92408

*Corresponding author

\begin{abstract}
In this study AA5754 and A6061 alloys have been butt welded to each other by using friction stir welding (FSW). At constant tool geometry and tool angle experiments were carried out, joints were performed using different welding speed, rotation speed and especially tool press force. The mechanical properties of the welded samples were determined by using tensile test, bending test and micro hardness. Generated microstructure and hardness profile was obtained in the welding zone. In this friction stir welding study the parameters which affect the joint structure are the tool press force, welding speed and tool rotation speed which were determined. At the end of study it is determined that AA5754 and AA6061 alloys can be successfully welded by using Friction Stir Welding method under different tool press forces at least $6 \mathrm{kN}$.

Keywords: Friction stir welding (FSW), AA5754, AA6061, Aluminum alloy, Tool press force.
\end{abstract}

\section{Introduction}

Friction-stir welding (FSW) was invented at The Welding Institute (TWI) of UK in 1991 as a solid state joining technique and it was initially applied as a solid-state joining technique and it was applied to aluminum alloys [1]-[2]. Although FSW has evolved as a technique of joining of aluminum alloys, it is used for a variety of material groups including steels and polymers [3]-[2-4-5]. FSW assures the absence of porosity, distortion and residual stresses, which are typical defects of the fusion welding processes, and the possibility to operate in all positions without protective gas. Alloys difficult to weld like the 5000 and 7000 aluminum series have successfully been welded using FSW. The process uses a shouldered rotating tool with a profiled pin that penetrates the clamped parts to be joined; the tool then starts to move along the join line (Figure 1 ). The heat produced by friction, softens the alloy and the pin stirs the material of the joint until the sheets are joined. The stirring of one material into the other is associated with a solid-state flow, with a very high deformation, and involves recrystallization of a portion of the joint (weld nugget). These extremely fine recrystallized grains are known to slide one to other, leading to a super plastic flow that accommodates the FSW process [6]-[7]-[8].

The schematic illustration of the FSW is given in Figure 1. The side of the weld where the local direction of the tool is the same as traversing direction is called the advancing side (AS). Similarly, the side where the directions are opposite and the local movement of the shoulder is against the traversing direction is called the retreating side (RS) [2-4-5]-[9]. This difference can cause asymmetry in heat transfer, material flow and the properties of the two sides of the weld [3].

The welding zones occurring in FSW have been given in Figure 2 . Here, the base metal is the zone which has not been affected by the heat and deformation forming in the welding zone. Stir zone (SZ) is the main area which is affected most by the heat effect and plastic deformation and where changes occur in the mechanical properties and microstructure-due to the friction and stirring of the tool pin and shoulder. Thermo mechanical affected zone (TMAZ) in this region, the material has been plastically deformed by the friction stir welding tool and significant changes occur in the micro structure. Heat Affected Zone (HAZ) is the region which is affected only by heat and no macro plastic deformation should be visible [2]-[10].

AA5754 and AA6061 alloys are widely used in industrial and manufacturing sector and they have mechanical properties which are close to each other. Increased strength by strain hardening method AA5754-H22 alloys come to the fore with resistance corrosion properties and for this reason they are widely used in automotive and ship building industry. Increased strength by aging method AA6061-T6 alloys which is widely used in defense industry, ship building and aerospace industry. Especially for AA6061 alloys FSW method is a more convenient method than other welding applications. Due to the high welding temperatures in fusing welding methods, decreasing strength in welding zones are usually seen depending on the over aging. But in FSW, as a result of being solid state welding method in welding zones, lowest temperatures occur and the minimum decreasing strength occurs [2-4-5]-[11]-[13].

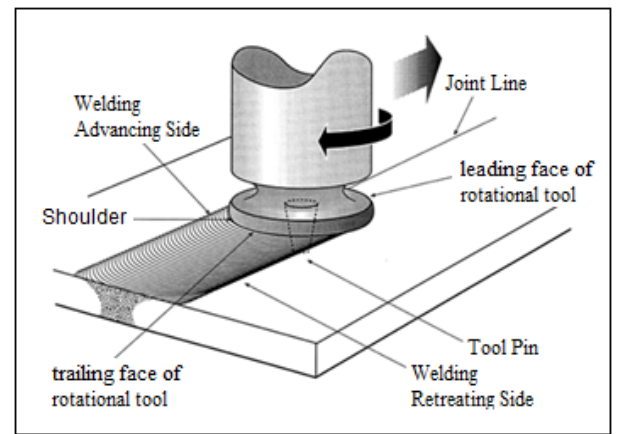

Figure 1: The schematic illustration of the FSW. 


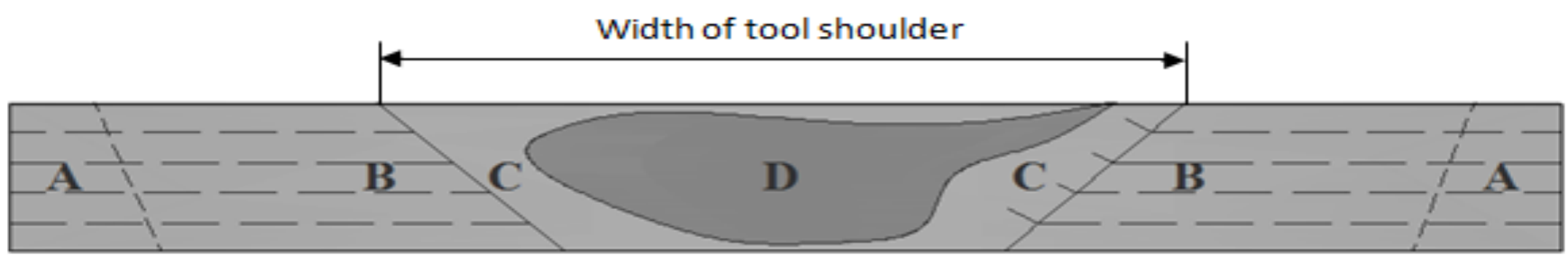

Figure 2: The welding zones forming in the jointed samples A: Base Metal (BM) B: Heat Affected Zone (HAZ) C: Thermo Mechanical Affected Zone (TMAZ) D: Stir Zone (SZ) [11] (www.twi.co.uk, 2011).

So, due to different properties of these alloys which have close mechanical features, it's understood that they can be used together with various applications. In result, in practice a pair of this aluminum can be used together in marine and automotive industry by welding. To realize the need for joining these alloys, which is also widely used in automotive defense and marine industries, FSW which is under development, was determined to be the most suitable method [14].

In this study AA5754 and AA6061 alloys have been butt welded each other by using friction stir welding method and the effect of different welding parameters on welding structure were investigated. After the FSW the metallurgical internal structure and the effect of internal structure on mechanical properties of joint were investigated.

\section{Material and Method}

In this study AA5754-H22 and AA6061-T6 aluminum alloys have been used as a sample material for the Friction Stir Welding process. The mechanical properties and chemical components of these alloys (AISI) have been given in Table 1 and Table 2 respectively.

In the light of information obtained from literature review and preliminary tests, experiments have been carried out by using specified range of parameters as follows: $2^{\circ}$ tool tilt angle, 800 $\mathrm{rpm}$ rotational speed, $270 \mathrm{~mm} / \mathrm{min}$ welding speed and with modifying $6 \mathrm{kN}, 8 \mathrm{kN}$ and $10 \mathrm{kN}$ tool press force.

Tensile and bending tests, micro hardness measurements and metallographic measurements were studied on joined samples. The welding experiments were performed using a universal vertical milling machine as shown in Figure 3. A hydraulics table unit was put in this bench and experiments have been carried out by setting the tool press force in the determined and constant adjustments.

This FSW machine consists of universal milling machine, a data recording computer, digital temperature sensor, hydraulic loading mechanism, hydraulic unit and hydraulic unit control device.
The tool used for the FSW is made from hot work tool steel as a triangular pyramid which has a $16 \mathrm{~mm}$ shoulder dimension and $5 \mathrm{~mm}$ stir pin as shown in Figure 4.

The $20 \mathrm{~mm}$ parts of the beginning and end zones of the each friction stir welded sample considered as non homogeneous have been removed, left a side and not used for experiment. The rest of the homogenous welding zone is prepared as the samples to be used in examinations.

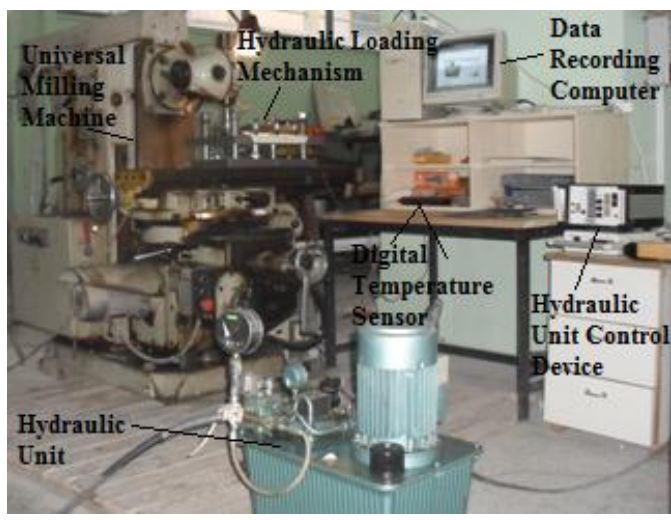

Figure 3: FSW mechanism.

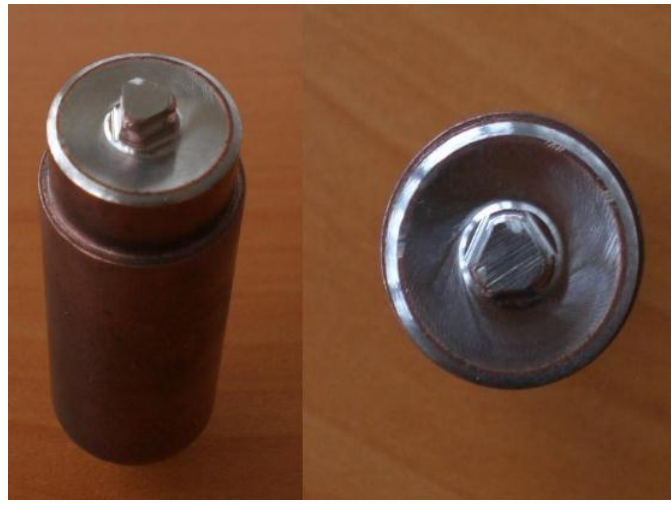

Figure 4: Side and top view of the tool.

Table 1: The mechanical properties of AA5754-H22 and AA6061-T6 alloys.

\begin{tabular}{lcccccc}
\hline Material & $\begin{array}{c}\text { Yield Point } \\
{[\mathrm{MPa}]}\end{array}$ & $\begin{array}{c}\text { Tensile Strength } \\
{[\mathrm{MPa}]}\end{array}$ & Hardness $\left(\mathrm{VH}_{0,2}\right)$ & $\begin{array}{c}\text { Young's Modulus } \\
{[\mathrm{Gpa}]}\end{array}$ & $\begin{array}{c}\text { Elongation at } \\
\text { Break } \\
{[\%]}\end{array}$ & $\begin{array}{c}\text { Energy at Break } \\
{[\mathrm{J}]}\end{array}$ \\
\hline AA5754-H22 & 190 & 253 & 78 & 60,87 & 13,6 & 12,37 \\
AA6061-T6 & 217 & 242 & 90 & 66,21 & 12,1 & 10,6 \\
\hline
\end{tabular}

Table 2. Chemical composition of AA5754-H22 and AA6061-T6 alloys.

\begin{tabular}{|c|c|c|c|c|c|c|c|c|c|c|c|c|}
\hline \multicolumn{13}{|c|}{ Chemical Composition (weight \%) } \\
\hline Material & $\mathrm{Si}$ & $\mathrm{Fe}$ & $\mathrm{Cu}$ & $\mathrm{Mn}$ & $\mathrm{Mg}$ & $\mathrm{Cr}$ & $\mathrm{Ni}$ & $\mathrm{Zn}$ & $\mathrm{Ti}$ & $\mathrm{Ga}$ & V & $\mathrm{Al}$ \\
\hline AA5754-H22 & 0,15 & 0,32 & 0,01 & 0,16 & 3,16 & - & - & - & 0,02 & - & - & 96,08 \\
\hline AA6061-T6 & 0,54 & 0,21 & 0,24 & 0,07 & 0,98 & 0,1 & 0,005 & 0,1 & 0,012 & 0,014 & 0,014 & 97,67 \\
\hline
\end{tabular}


The FSW samples used in mechanical and metallographic experiments were removed as shown in Figure 5. Tensile experiment, bending experiment, micro hardness measurements and metallographic experiments were performed with FSW samples. Tensile tests and bending tests have been carried out in accordance with TS EN 876 and TS 282 EN 910, TS EN 876 and TS 282 EN 910 standards respectively.

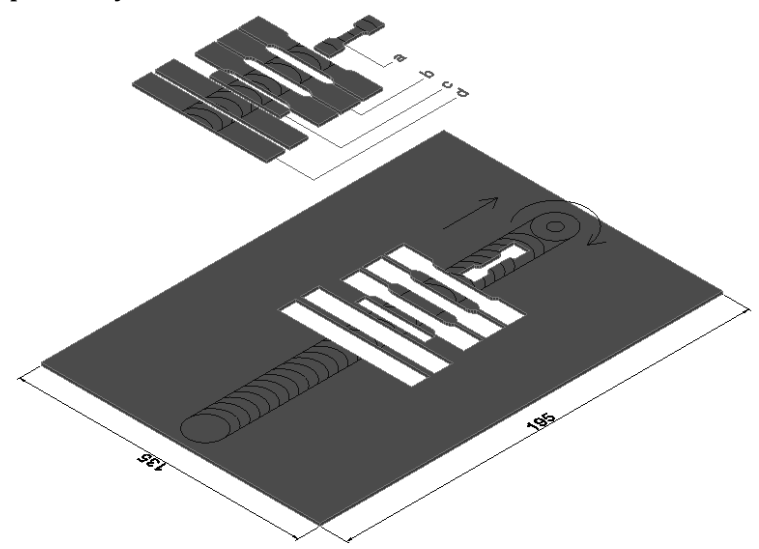

Figure 5: Extraction plan of tests samples from combined plates a) Longitudinal tensile specimen, b) Transverse tensile sample, c) Metallography sample, d) Bending sample.

\section{Results and Discussion}

\subsection{Temparature Measurements}

To measure the temperature of the samples during the experiment, the thermocouples are placed in the center of the pin line. The highest temperature was measured as $376^{\circ} \mathrm{C}$.

\subsection{Macrostructure and Microstructure Features}

In the examination done at macro level, it was observed that the surface roughness of the weld nuggets is close to one another in all the samples and very low level. No defects such as a fracture or void have been observed in the surface appearance of the welded samples.

The microstructure of joined area of welded samples is shown in Figure 6. The figure shows scanning electron microscope (SEM) images of the joined zones of samples. The micrographs are used to name 130 to 1700 magnifications, to get better interpretation of the different regions of pictures of the samples.

When analyzing these pictures, different sizes of micro-pores can be seen in two alloys. These pores are gas and pulling pores when formed during the production of materials. In the welding nugget, AA6061 alloy which is scattered through the AA5754 alloy can be seen in Figure 6A, 6C and 6D, there are onion rings which result from joining. AA6061 alloy structures are shown in Figure 6B and 6b, where the shoulder has been rolled up to the surface of sample. When analyzing this structure, simultaneous excessive plastic deformation of AA6061 alloy can be seen. As a result of excessive plastic deformation, pores which existed primarily, entered in a specific order turning towards. This situation is a result of being on the retreating side of AA6061 alloy during the welding.

In figure $6 \mathrm{E}$ and $6 \mathrm{e}$, discrete region is not combined for the poor press force at the bottom of the stirring zone. This section appears in the form of the crack as the stirring pin is approximately $0,2 \mathrm{~mm}$ shorter than plate thickness. Therefore, stirring pin couldn't reach to the bottom of the material during the welding. No fault, space and defect have been observed on the welding nugget. From the results of selected parameters and especially the effect of stirring pin, the materials have been welded successfully. Longitudinal tensile specimen's tensile strength and ductility (elongation \% values were higher than base materials values. This effect is consistent with findings in the literature specified [2]-[9]-[15].

Figure 6 clearly shows, stirring zone, TMAZ and HAZ of the welding section of AA5754 and AA6061 alloys. Also as shown in Figure 6, in the stirring zone the boundary between AA5754 and AA6061 can be easily seen. This Figure shows the applied joining operation is diffusion free and being mechanical form of the mixture.

\subsection{Mechanical Properties}

The hardness value of the base AA5754-H22 alloy measured before the welding is $78 \mathrm{VH}_{0,2}$ and AA6061 alloy measured as $90 \mathrm{VH}_{0,2}$. In the joint zones of the samples obtained in the welding process, the hardness values measured in all the samples vary from 60 to $92 \mathrm{VH}$ as shown in Figure 7.

Temperature values that were produced during welding are higher than strain hardened AA5754 alloy's recrystallization temperature $\left(\approx 320^{\circ} \mathrm{C}\right)$ and aged AA6061 alloy's aging temperature $\left(160^{\circ} \mathrm{C}\right)$. So the effect of welding temperature is higher than the AA6061 alloy hardness on the AA5754 alloy hardness effect. The reason of this result is, with the reached maximum temperature between $330-376{ }^{\circ} \mathrm{C}$ during welding, primarily caused over aging of AA6061 alloy. On the 5754 side, harness value decrease has been fewer. The reason of this result is reached maximum temperature during welding is close to the AA5754 alloy's recrystallization temperature region's base limit. So, the welding temperature's effect time is not enough strain hardened AA5754 alloys recrystallization. Maximum decrease in hardness has seen in HAZ at the both side.

Closer to the center of the source a significant increase in hardness is observed in both sides and hardness reaches peak value in the centre of welding zone. The effective mechanism is excessive plastic deformation by the stirring of the pin and following the effect of recrystallization. By the effect of stirring and deformation, stirred recrystallized materials occur. Therefore thinner grain size, hardness and strength increase accordance with Hall-Petch equation [2-4-5]-[3]-[15].

As seen in Figure 7, tool press force directly affects the hardness value of the materials. With the increasing tool press force, they also increase observed in the overall hardness values. The reason of this result is, with the increased tool press force, temperature ranks increase and strength of alloys decrease. So alloys viscosity of alloys increases and stirring becomes more homogenous [14].

Transverse tensile specimens have been broken outside of welding region. They have been broken HAZ of AA6061 alloy's side. Longitudinally tensile specimens have been broken in the middle of gauge length region. Table 3 shows the results of mechanical properties obtained from the tensile samples.

As shown in Table 3, after friction stir welded AA5754 and AA6061 alloy's tensile and yield strength of transverse-tensile sample is $86 \pm 3 \%$ and $78 \pm 5 \%$ of base material. These values indicate the success of FSW method. Tensile and yield strength of welded samples increase with tool press force. This can be explained under three headings. 


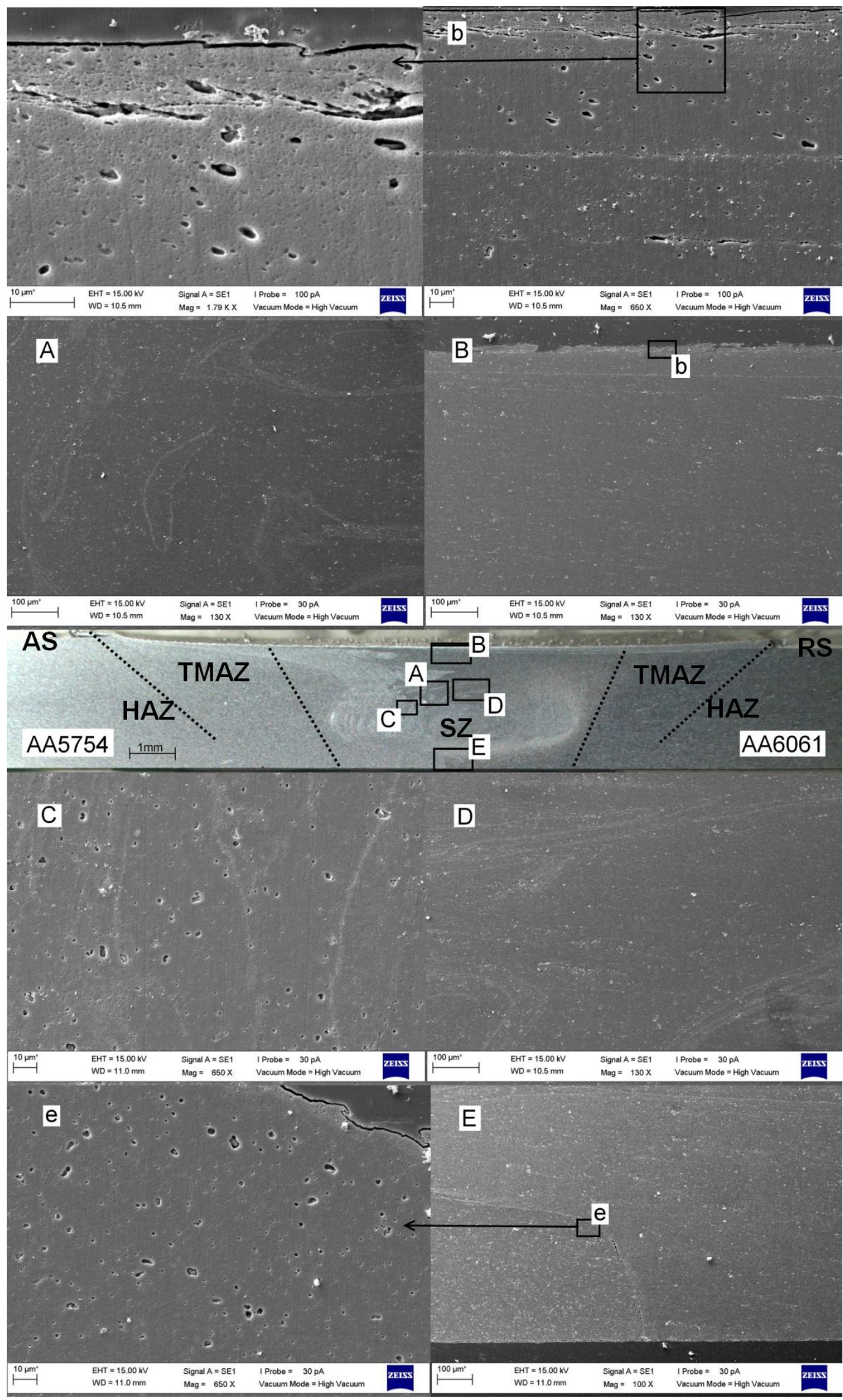

Figure 6: The SEM images of joined samples. 


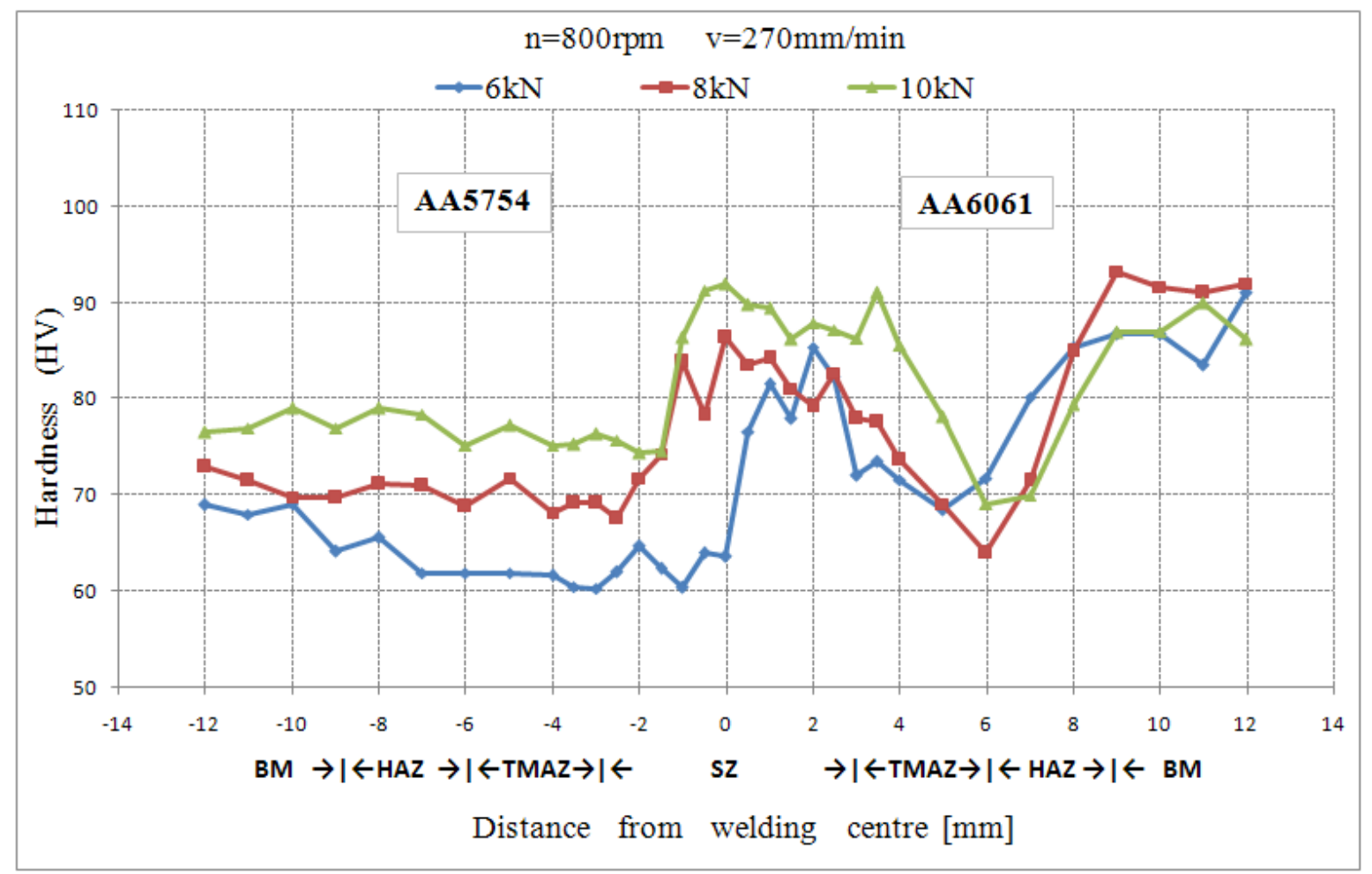

Figure 7: The harness distribution of the welding zone.

Table 3: Mechanical properties obtained from tensile samples.

\begin{tabular}{lcccc}
\hline \multicolumn{1}{c}{$\begin{array}{c}\text { Tensile } \\
\text { Samples }\end{array}$} & $\begin{array}{c}\text { Tensile } \\
\text { Strength } \\
{[\mathrm{MPa}]}\end{array}$ & $\begin{array}{c}\text { Yield Point } \\
{[\mathrm{MPa}]}\end{array}$ & $\begin{array}{c}\text { Elongation } \\
\text { at Break } \\
{[\%]}\end{array}$ & $\begin{array}{c}\text { Energy at } \\
\text { Break [J] }\end{array}$ \\
\hline $\begin{array}{l}\text { Base Material } \\
\text { AA5754 }\end{array}$ & 253 & 190 & 13,6 & 12,37 \\
$\begin{array}{l}\text { Base Material } \\
\text { AA6061 }\end{array}$ & 242 & 217 & 12,1 & 10,6 \\
$\begin{array}{l}\text { Transverse } \\
\text { 6kN }\end{array}$ & 203 & 138 & 7,2 & 5,33 \\
$\begin{array}{l}\text { Transverse } \\
\text { 8kN }\end{array}$ & 209 & 148 & 6,84 & 4,86 \\
$\begin{array}{l}\text { Transverse } \\
\text { 10kN }\end{array}$ & 215 & 155 & 6,44 & 4,59 \\
$\begin{array}{l}\text { Longitudinally } \\
\text { 6KN }\end{array}$ & 291 & 196 & 20 & - \\
$\begin{array}{l}\text { Longitudinally } \\
\text { 8KN }\end{array}$ & 320 & 229 & 40,3 & - \\
$\begin{array}{l}\text { Longitudinally } \\
\text { 10KN }\end{array}$ & 293 & 199 & 39,1 & - \\
\hline
\end{tabular}

The first matter; welding temperature increases with increasing temperature and hence materials can confuse each other easily and become more homogenous. The second; with increasing tool press force, materials weld under more stress and therefore more fine grained structure exist and accordingly strength increases [16].

The third reason is with increasing tool press force, stirring pin reaches more bottom of the materials and welding can make more along the thickness. Elongation of the welded transverse-tensile sample is $57 \pm 4 \%$ and toughness is $46 \pm 4 \%$ of base material. This can be explained as follows; since welded region have higher-strength than base materials and the elongation of the sample actually gets from the base material sides, not from welding portion by the tensile test [10]-[17]. The tensile strength of longitudinal-tensile samples are $25 \%$ more than base material, and yield strength values are similar with base material's values. The rise of strength values of longitudinal tensile sample comes from the welded zone which is due to fine grained structure of the welded zone. Therefore thinner grain size, hardness and strength increase accordance with Hall-Petch equation [3]-[15]. Elongation values of the longitudinal-tensile samples are approximately $170 \%$ more than base material's value. This can be explained as follows; by the effect of deformation during welding, generated heat provides the dislocations in grain and is thought to lead to an increase in toughness.

Tensile and yield strength of longitudinal tensile samples are considerably higher than that of transverse- tensile samples. It was achieved that even the yield strength of longitudinal tensile samples are higher than the tensile stress of transverse sample which are both obtained from the same samples. The main difference between two samples is nonhomogenous structure of the transverse-tensile sample.This situation happens when tensile affecting to sample at transverse tensile test which form plastic deformation at HAZ region of welding zone. On the contrary, increase in strength of stirring zone prevent formaton of plastic deformtion at welding zone. For this reason, at the transverse tensile samples, welding seam area can not contribute to measured elongation value [10]. Therefore, at these samples during assessment of strain capability, it will lead to obtain incorrect results when the first measurement region covers both of the regions that have different mechanical properties. However, parts including welding seam in the usage of engineering products are generally manipulated with these conditions [10]. In the case of the assessment of the engineering products including welding seam, it is required to determine the strain capability of the welding region. In the conducted experiments, $180^{\circ}$ bending was imposed in such a way that root zone (probably includes welding seam crack) was placed on the inner side. From bending experiments on the surfaces of the obtained samples, no crack indication was detected. The results of the 
bending experiments show that experimental samples merged with frictional welding have sufficient ductility.

In conclusion, the results obtained from joining AA5754-H22 and AA6061-T6 (AISI) aluminum alloys by using friction stir welding process under $800 \mathrm{rpm}$ rotation speed, $270 \mathrm{~mm} / \mathrm{min}$ welding speed and $6 \mathrm{KN}, 8 \mathrm{kN}$ and $10 \mathrm{kN}$ tool press force conditions are as follows;

1. AA5754-H22 and AA6061-T6 alloys can be successfully joined by FSW process.

2. The weakest zone in the welding process stays out of the joint zone. Stays in the HAZ of AA6061 alloy.

3. Decrease of the welding structure's strength is approximately $14 \%$ to the base materials.

4. The resulting temperature more affected AA6061 alloy than AA5754 alloy more.

5. Strength and hardness of welded structure increase with tool press force.

6. The welding region has acceptable shape change ability for engineering applications.

\section{Acknowledgment}

We owe great many thanks to a great many people who helped and supported us during the writing of this paper. We express thanks to Mr. Gençağa PÜRÇEK who lent us knowledge and experience and for the use of all facilities in laboratory studies. We also would like to thank laboratory members that help in all matters in laboratory works.

\section{References}

[1] Dawes, C. and Thomas, W., "Friction stir joining of aluminum alloys" Bulletin 6, 124-127, 1995.

[2] Çam G., 'Friction Stir Welded Structural Materials: Beyond Al-Alloys', Int. Mater. Rev., (56) 1, 1-48. 2011.

[3] Nandan, R., Debroy, T. and Bhadeshia, H. K. D. H., "Recent advances in friction stir welding-process, Weldment Structure and Properties", Progress in Materials Science, (53), 980-1023, 2008.

[4] Çam G., "Sürtünme Karıştırma Kaynağı Uygulamalarındaki Son Gelișmeler", Makina Tek., (120) 48-58, 2007.

[5] Çam G., "Sürtünme Karıştırma Kaynağı Uygulamalarındaki Son Gelişmeler", TMMOB Makina Mühendisleri Odası, Kaynak Teknolojisi VI. Ulusal Kongresi, 35-43, Ankara. 910 Kasim 2007.

[6] Benavides S., Li, Y., Murr, L.E., Brown, D. and McClure, J. C., Scripta Materialia, 41, 809, 1999.
[7] Paola, M., Falchero, A., Cabibbo, M., Evangelista, E., Meccia, E., and Spigarelli, S., "Mechanical and microstructural characterization of an aluminum friction stir-welded butt joint" Metallurgical Science and Technology, 20. 17-21, 2002.

[8] G. Çam and M. Koçak, Joining of Advanced Materials, Area 6: Materials Science and Engineering, Topic 6.36.4: Materials Processing and Manufacturing Technologies, edited by Rees D. Rawlings, in Encyclopedia of Life Support Systems (EOLSS), Developed under the auspices of the UNESCO, Eolss Publishers, Oxford, UK.

[9] Threadgill, P. L., "Terminology in friction stir welding" Sci. and Tech. of Weld. and Joining, 12.4, 357-360, 2007.

[10] Küçükömeroğlu T., Aktarer S. M., Yılmaz H. Kara, L. “ The Structural Examination of IF 7114 Steel Joint by Friction Stir Welding" International Congress on Advances in Welding Science and Technology for Construction, Energy and Transportation Systems (AWST-2011), October pp. 193-198.

[11] http://www.twi.co.uk/content/fswintro.html, Friction Stir Welding Rotary. 15 May 2011.

[12] Anderson T., "The advancement of Al within welding fabrication industry and product design applications" Svetsaren, 3, 3-5, 2000.

[13] Külekçi M.K. ve Şık A., "Sürtünme Karıștırma Kaynağı ile Alüminyum Alaşımı Levhaların Birleștirilmesi ve Elde Edilen Kaynaklı Bağlantıların Mekanik Özellikleri" Süleyman Demirel Üniv. Fen Bil. Ens. Derg., 70-75, 2003.

[14] Yılmaz, H., "The Investigation of the Weldability of AA5754 and AA6061 Alloys by Friction Stir Welding" Master Thesis, No:406208, Paje 115, Trabzon. June, 2011, Trabzon.

[15] Mishra, R.S. and Ma, Z.Y., "Friction stir welding and processing" Mater. Sci. and Eng.., R50, 1-78, 2005.

[16] Lomolino S., Tovo, R., Dos Santos, J., " On the fatigue behavior of the microstructure and mechanical properties of friction stir welded 6005 aluminum alloy" International Journal Fatigue, 305-316, 2005.

[17] Küçükömeroğlu, T., Akyüz, H. and Çalışkan H., "Effects of Some Parameters to AA5754-Cuzn30 Alloys on the Friction Stir Spot Welding Process" 13th. International Materials Symposium, Ekim, pp24-28, Denizli, 2010.

[18] Thomas, W. M. and Nicholas, E. D., "Friction stir welding for the transportation industries" Materials and Design, 18, 269-273, 1997. 